American Journal of Environmental Sciences 3 (4): 183-187, 2007

ISSN $1553-345 \mathrm{X}$

(C) 2007 Science Publications

\title{
Comparison Between Biological Treatment and Chemical Precipitation for Nitrogen Removal from Old Landfill Leachate
}

\author{
Long Tengrui, Anas F. Al-Harbawi, He Qiang and Zhai Jun \\ Faculty of Urban Construction and Environmental Engineering, Chongqing University, China, 400045
}

\begin{abstract}
The study reports the results of a laboratory scale investigation aimed at evaluating the effectiveness of mature municipal landfill leachate treatment by a biological stage (used SBBR as a biological treatment) and Chemical precipitation (Used MAP precipitation (magnesium ammonium phosphate)) to study the nitrogen removal capabilities for treatment of sanitary landfill leachate containing high ammonia concentration, and the comparison between them. The monitored sample taken from the Chang Sheng bridge landfill site in Chongqing city-China, has its concentrations of $\mathrm{COD}, \mathrm{BOD}_{5}$, and $\mathrm{NH}_{3}-\mathrm{N}$ about 1650,75 and $1100 \mathrm{mg} / \mathrm{l}$ respectively. The results from SBBR showed that after two months long period of domestication and one month period of stability, the ammonia nitrogen removal efficiency reached to $99 \%$ in the SBBR reactor, at nitrogen loading rate $0.51 \mathrm{~kg}$ $\mathrm{TN} / \mathrm{m}^{3}$ per day and HRT was 9 hours, met to Chinese standards for discharge. The results of the MAP precipitation was technically effective to remove the high $\mathrm{NH}_{3}-\mathrm{N}$ strength of over $1100 \mathrm{mg} / \mathrm{l}$ from the raw leachate at molar ratio of $\mathrm{Mg}^{2+}: \mathrm{NH}_{4}{ }^{+}: \mathrm{PO}_{4}^{-3}$ of $1: 1: 1$, they demonstrated a very satisfactory removal of ammonia; an initial $\mathrm{NH}_{3}{ }^{+}-\mathrm{N}$ concentration of $1100 \mathrm{mg} / \mathrm{l}$ contained in the raw leachate was quickly reduced to $28 \mathrm{mg} / \mathrm{l}$ within $15 \mathrm{~min}$, while the $\mathrm{pH}$ producing a maximum removal of ammonia was 9.0. The percent removal of ammonia after treatment by MAP was $97.5 \%$.
\end{abstract}

Key words: Biological treatment, SBBR, MAP, struvite

\section{INTRODUCTION}

Sanitary landfill is an engineered of disposing solid wastes that minimizes environmental hazards ${ }^{[1]}$. It has been suggested to be the most economical and environmentally acceptable method for disposal of municipal solid wastes ${ }^{[2]}$. The sanitary landfill site is carefully selected. Since 1970 the design of landfill sites for disposal of municipal, industrial and commercial refuses include barrier systems as well as leachate collection system to prevent contamination of surrounding environment. Landfill leachate is a complicated waste, and it always contains high strength pollutants which have an adverse effect on the environment ${ }^{[3]}$. It has been generally known as a highstrength wastewater that is most difficult to deal with. This is due primarily to its large variability of organic, inorganic and heavy metal contents, strongly depending on the age and type of solid wastes of a landfill site ${ }^{[4]}$. Landfill leachate is formed by the percolation of rainwater through domestic refuses. The water causes leaching of soluble salts and partly biodegraded organic compounds, responsible for a foul-smelling, darkcolored leachate. It may also contain fine particles of soil from the daily cover. Bacterial degradation starts under aerobic conditions as soon as the wastes are deposited in the landfill, generating high temperatures. The system becomes anaerobic following rapid depletion of oxygen, much cooler and for less reactive $^{[5]}$.

Several factors affect the composition of landfill leachate. These include the age of the landfill, the nature of the waste (solid or liquid), the source of waste (municipal, industrial, commercial, mining) and the amount of precipitation. A young leachate in the acidogenic phase characterized by a high organic fraction and a $\mathrm{BOD}_{5} / \mathrm{COD}$ ratio greater than 0.4 , it can be easily biodegraded and it is weakly acidic, consequently mobilizing heavy metals. An older leachate in the methanogenic phase is not easily biodegrade as a young leachate. It contains refractory organic compounds, high concentrations of ammonia and is characterized by higher $\mathrm{pH}$ values ${ }^{[6]}$.

Many different techniques are currently in use to treat landfill leachates. The majority of them are adaptations of wastewater treatment techniques and can be divided in two main categories: biological treatment and physical / chemical treatments. The biological

Corresponding Author: $\quad$ Long Tengrui, Faculty of Urban Construction and Environmental Engineering, Chongqing University, China, 400045 
treatment was successfully used for leachate with a high organic strength and $\mathrm{BOD} / \mathrm{COD}$ ratio $(>0.5)$, particularly in leachates from recently placed wastes (less than 5 years) where readily biodegradable substances like volatile fatty acids comprise a large proportion of the organic material. Many small scale experimental studies showed that BOD and COD could be substantially reduced. However, leachates from older, more decomposed waste are less amenable to biological process, because a higher proportion of organic materials consist of relatively refractory materials like humic and fulvic acids ${ }^{[7]}$.

Conventional nitrification-denitrification biological processes, which have been widely utilized for ammonium removal from municipal and many industrial wastewaters, are not appropriate for treating landfill leachate because of the lack of sufficient electron donors in leachate and the high energy requirement for aeration. While new biological techniques like short-cut nitrification/denitrification and anaerobic ammonium oxidization have demonstrated potential in solving the above problems, they are still under study and it is not yet possible to constantly control the nitrification process in the nitrite-formation dominating step ${ }^{[9]}$.

The Sequencing Batch Biofilm Reactor (SBBR) is a system for wastewater treatment which combines the operating and performance advantages of the Sequencing Batch Reactor (SBR) and biofilm operation. This hybrid system provides the operational flexibility necessary for biological treatment of wastewaters containing volatile organic components with minimal fugitive emissions, treatment of low strength wastewaters which are difficult to treat in suspended growth reactors, and treatment of wastewaters containing surfactants. The SBBR also maintains the operational flexibility of the SBR for nutrient removal ${ }^{[8]}$.

The method of MAP precipitation has also been extensively studied to treat wastewater with high $\mathrm{NH}_{3}$ content, and the $\mathrm{NH}_{3}-\mathrm{N}$ concentration could be reduced from $5618 \mathrm{mgL}^{-1}$ to $112 \mathrm{mgL}^{-1}$ within 15 min under a molar ratio of $\mathrm{Mg}^{2+}: \mathrm{NH}_{4}^{+}: \mathrm{PO}_{4}{ }^{3-}$ of $1: 1: 1$ for treating landfill leachate. Chemical precipitation as MAP can form virtually or completely insoluble compounds that can be easily separated from the water phase. The basic chemical reaction to form MAP has been expressed in Eq. (1). The theoretical amounts of chemicals needed to precipitate $\mathrm{NH}_{4}-\mathrm{N}$ can be calculated from the equations (2), (3), (4) ${ }^{[10]}$.

The objective of this study was to evaluate the possibility of using SBBR as a biological treatment and
MAP precipitation as a chemical treatment to remove the ammonia from old landfill leachate, and comparison between them.

$$
\begin{aligned}
& \mathrm{Mg}_{2}+\mathrm{PO}_{4}^{3-}+\mathrm{NH}_{4}+6 \mathrm{H}_{2} \mathrm{O} \rightarrow \\
& \mathrm{MgNH}_{4} \mathrm{PO}_{4} \cdot 6 \mathrm{H}_{2} \mathrm{O} \downarrow \mathrm{pKs}=12 \cdot 6\left(25^{\circ} \mathrm{C}\right) \\
& \mathrm{MgCl}_{2} \cdot 6 \mathrm{H}_{2} \mathrm{O}+\mathrm{Na}_{2} \mathrm{HPO}_{4} \cdot 12 \mathrm{H}_{2} \mathrm{O}+\mathrm{NH}_{4}^{+} . \\
& \rightarrow \mathrm{MgNH}_{4} \mathrm{PO}_{4} \cdot 6 \mathrm{H}_{2} \mathrm{O} \downarrow+2 \mathrm{NaCl} \\
& \mathrm{MgO} \mathrm{H}_{3} \mathrm{PO}_{4}+\mathrm{NH}_{4}^{+} \rightarrow \mathrm{MgNH}_{4} \mathrm{PO}_{4} 6 \mathrm{H}_{2} \mathrm{O} \downarrow+\mathrm{H}_{2} \mathrm{O} \\
& \mathrm{Ca}\left(\mathrm{H}_{2} \mathrm{PO}_{4}\right)_{2} \cdot \mathrm{H}_{2} \mathrm{O}+\mathrm{MgSO}_{4} \cdot 7 \mathrm{H}_{2} \mathrm{O}+\mathrm{NH}_{4}^{+} \\
& \rightarrow \mathrm{MgNH}_{4} \mathrm{PO}_{4} \cdot 6 \mathrm{H}_{2} \mathrm{O} \downarrow+\mathrm{CaSO}_{4} \downarrow
\end{aligned}
$$

\section{MATERIALS AND METHODS}

The leachate investigated in this experiment was taken from the ChangSheng Bridge Landfill inside Chongqing city. The composition can be showed in Table 1.

From Table 1, the landfill leachate is characterized as low $\mathrm{C} / \mathrm{N}$ ratio, low $\mathrm{BOD}_{5} / \mathrm{COD}$ ratio and high contents of $\mathrm{NH}_{3}-\mathrm{N}\left(1100 \mathrm{mgL}^{-1}\right)$, which show the leachate can be classified as "old" and nonbiodegradable.

The SBBR was carried out by a lab-scale SBBR made of a cylindrical reactor (geometric volume $24 \mathrm{~L}$, working liquid volume $12 \mathrm{~L}$ ). The SBBR reactors (12 1 capacity) were made from acrylic plastic (5 $\mathrm{mm}$ thick). The dimensions of the reactor were $0.29 \mathrm{~m}$ (diameter) by $0.35 \mathrm{~m}$ (height). Air pump was used for supplying air for the reactor. The air diffuser for aeration was set up on the top of the settling zone to allow the biomass of large aggregates detached from the biofilm to settle during the aeration. The packing ratio of the carriers was $30 \%$.

Figure 1 represents schematic diagram of the experimental apparatus. Units of fibrous carriers hung uniformly from the top of the reactor. Each unit of the fibrous carriers consisted of many bunches of fibers. The 24 hrs operation cycle comprised a 30 min filling period, during the acclimatization period.

Table 1: The Composition of the investigated landfill leachate

\begin{tabular}{lll}
\hline Parameter & Unit & Value \\
\hline $\mathrm{COD}$ & $\mathrm{mg} \mathrm{L}^{-1}$ & 1650 \\
$\mathrm{BOD}_{5}$ & $\mathrm{mg} \mathrm{L}^{-1}$ & 75 \\
$\mathrm{NH}_{3}-\mathrm{N}$ & $\mathrm{mg} \mathrm{L}$ & 1100 \\
$\mathrm{TN}$ & $\mathrm{mg} \mathrm{L}^{-1}$ & 1350 \\
$\mathrm{PO}_{4}-\mathrm{P}$ & $\mathrm{mg} \mathrm{L}^{-1}$ & 12 \\
$\mathrm{SS}$ & $\mathrm{mg} \mathrm{L}^{-1}$ & 100 \\
$\mathrm{pH}$ & ---- & $8 \sim 9$ \\
\hline
\end{tabular}




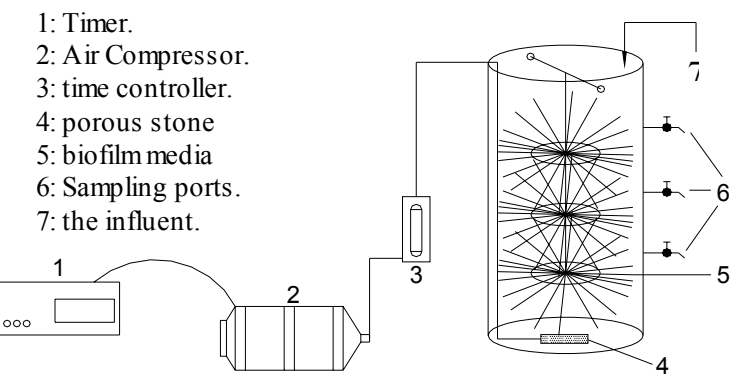

Fig. 1: Schematic diagram of the SBBR system

The MAP precipitating tests were carried out in 500-ml beakers as a batch mode. The experimental procedures were outlined below:

1. Weigh chemicals (see Table 2) to measure the 500$\mathrm{ml}$ raw leachate for each test;

2. Put the measured leachate samples and the weighed chemicals into beakers;

3. Put the samples in the jar test devise and start the mixing and monitor $\mathrm{pH}$ of the samples;

4. The reaction is $15 \mathrm{~min}$ until a stable $\mathrm{pH}$ indicated (equilibrium state);

5. Stop the mixing and leave the samples to settle for 15 min;

6. Adjust $\mathrm{pH}$ for the minimum MAP solubility with $\mathrm{NaOH}$ solution;

7. Collect the supernatant above the MAP precipitate to measure the required parameters;

8. Use mixed liquor to examine its characteristics.

Table 2: Amount of chemicals added in the $500 \mathrm{ml}$ leachate at various $\mathrm{Mg}^{2+}: \mathrm{NH}_{4}^{+}: \mathrm{PO}_{4}^{3-}$

\begin{tabular}{|c|c|c|}
\hline $\mathrm{Mg}^{2+}: \mathrm{NH}_{4}^{+}: \mathrm{PO}_{4}{ }^{3-}$ & $\mathrm{Mgcl}_{2} \cdot 6 \mathrm{H}_{2} \mathrm{O}$ & $\mathrm{Na}_{2} \mathrm{HPO}_{4} \cdot 12 \mathrm{H}_{2} \mathrm{O}\left(\mathrm{mgL}^{-1}\right)$ \\
\hline $\begin{array}{lll}1 & 1 & 0\end{array}$ & 7.975 & 0.000 \\
\hline $\begin{array}{lll}1 & 1 & 0.5\end{array}$ & 7.975 & 7.032 \\
\hline $\begin{array}{lll}1 & 1 & 0.75\end{array}$ & 7.975 & 10.548 \\
\hline $\begin{array}{lll}1 & 1 & 1\end{array}$ & 7.975 & 14.064 \\
\hline $\begin{array}{lll}1 & 1 & 1.1\end{array}$ & 7.975 & 15.470 \\
\hline $1: 1 \quad 1.25$ & 7.975 & 17.580 \\
\hline $\begin{array}{lll}1 & 1 & 1.5\end{array}$ & 7.975 & 21.096 \\
\hline $\begin{array}{lll}0 & 1 & 1\end{array}$ & 0.000 & 14.064 \\
\hline $\begin{array}{lll}0.5 & 1 & 1\end{array}$ & 3.990 & 14.064 \\
\hline $\begin{array}{lll}0.75 & 1 & 1\end{array}$ & 5.980 & 14.064 \\
\hline $\begin{array}{lll}1.1 & 1 & 1\end{array}$ & 8.773 & 14.064 \\
\hline $1.25 \quad 1 \quad 1$ & 9.969 & 14.064 \\
\hline $\begin{array}{lll}1.5 & 1 & 1\end{array}$ & 11.963 & 14.064 \\
\hline
\end{tabular}

\section{RESULTS AND DISCUSSION}

Use of SBBR system to remove ammonia $\left(\mathrm{NH}_{3}-\mathrm{N}\right)$ as a biological treatment of the old landfill leachate:
Each cycle of the SBBR was divided into fill, react and draw periods. The react time for each cycle was the total cycle time less $1 / 2$ hour for the fill and draw time (30 min). After 2 months acclimatization with a Nitrogen loading rate of $0.41 \mathrm{~kg} \mathrm{TN} \mathrm{m}^{-3}$ per day, the SBBR had reached a steady state. Then cycle time was reduced from 24 to $9 \mathrm{hrs}$ and the loading rate from 0.41 to $0.51 \mathrm{~kg} \mathrm{TN} \mathrm{m}^{-3}$ per day. The data obtained from the operation of the SBBR at the last cycle time are summarized in Table 3 and 4.

During the reaction, the concentration of the $\mathrm{NH}_{3}{ }^{-}$ $\mathrm{N}$ decreased gradually in the reactor until reached to 11 $\mathrm{mg} \mathrm{L} \mathrm{L}^{-1}$ as shown in Fig. 2. In Fig. 3 observed that there was accumulation of nitrite significantly in the first 3 hrs, the concentration of nitrite $\left(\mathrm{NO}_{2}\right)$ inside reactor increased with time and this point represents the maximum of nitrite concentration. After that the nitrite was converted through reaction and decreased with time. The reason of the nitrite accumulation was the presence of a lot of free ammonia inside the SBBR reactor restrained the nitrifier bacteria. In Fig. 4 we observed that the concentration of nitrate $\left(\mathrm{NO}_{3}\right)$ increased gradually, because the ammonia nitrogen inside the reactor was removed under thorough aeration and there was no denitrification.

Use of MAP to remove ammonia $\mathrm{NH}_{3}-\mathrm{N}$ as a chemical treatment of old Landfill Leachate:

Effect of $\mathbf{p H}$ : Struvite (MAP) precipitation reaction is highly dependent on $\mathrm{pH}$. To study the effect of the solution $\mathrm{pH}$ on the ammonia removal by use the Struvite (MAP), the molar ratio of $\mathrm{Mg}^{2+}: \mathrm{NH}_{4}^{+}: \mathrm{PO}_{4}{ }^{3-}$ was kept at 1:1:1. Fig. (5) demonstrated that the percent of ammonia removal increases, with the increase of $\mathrm{pH}$, and the optimum $\mathrm{pH}$ value was 9.0. Various authors have reported optimum $\mathrm{pH}$ values for struvite precipitation was the range of between 8.5 to 9.0 for different type of wastewaters such as anaerobic digester effluent, swine wastewater, sludge, and livestock waste $^{[11-15]}$.

Effect of molar ratio: The analytical results of supernatant demonstrated that $\mathrm{NH}_{3}-\mathrm{N}$ was efficiently decreased from an initial concentration of $1100 \mathrm{mg} / 1$ to as low as $28 \mathrm{mg} / 1$ at the $\mathrm{Mg}^{2+}: \mathrm{NH}_{4}{ }^{+}: \mathrm{PO}_{4}{ }^{3-}$ mole ratio of $1: 1: 1$, as shown in Fig. (6) demonstrated that the maximum removal of ammonia was $97.5 \%$. A high salinity formed in the treated leachate during precipitation using $\mathrm{MgCl}_{2} \cdot 6 \mathrm{H}_{2} \mathrm{O}$ and $\mathrm{Na}_{2} \mathrm{HPO}_{4} \cdot 12 \mathrm{H}_{2} \mathrm{O}$, which may inhibit microbial activity in a following biological treatment process. 
Am. J. Environ. Sci., 3 (4): 183-187, 2007

\begin{tabular}{lccccc} 
Table 3: & Operation conditions for the SBBR for ammonia removal \\
\hline HRT(h) & Loading rate $\mathrm{kg} /\left(\mathrm{m}^{3} \cdot \mathrm{d}\right)$ & Biofilm density to the total density & Effluent volume $(\mathrm{L})$ & Temp. $\left({ }^{\circ} \mathrm{C}\right)$ & Total volume $(\mathrm{L})$ \\
\hline 9 & 0.51 & $42 \%$ & 2 & $30-33$ & 12 \\
\hline
\end{tabular}

Table 4: The results of the SBBR effluent at the last cycle

\begin{tabular}{lllllll}
\hline Time $(\mathrm{hrs})$ & $\mathrm{PH}$ & $\mathrm{NH}_{3}-\mathrm{N}\left(\mathrm{mg} \mathrm{L}^{-1}\right)$ & $\mathrm{NO}_{2}-\mathrm{N}\left(\mathrm{mg} \mathrm{L}^{-1}\right)$ & $\mathrm{NO}_{3}-\mathrm{N}\left(\mathrm{mg} \mathrm{L}^{-1}\right)$ & $\mathrm{TN}\left(\mathrm{mg} \mathrm{L}^{-1}\right)$ & $\mathrm{DO}_{\left(\mathrm{mg} \mathrm{L}^{-1}\right)}$ \\
\hline 0 & 8.61 & 121.275 & 89.90838 & 730 & 1248.5 & 4.7 \\
1 & 8.34 & 98 & 79.92738 & 705 & 1243 & 4.7 \\
2 & 8.1 & 83.3 & 93.65125 & 860 & 1259.5 & 4.7 \\
3 & 7.91 & 66.64 & 96.97825 & 900 & 1245.75 & 4.6 \\
4 & 7.68 & 49 & 89.90838 & 1005 & 1240.25 & 4.6 \\
5 & 8.62 & 40.425 & 74.521 & 982.5 & 1239.5 & 4.5 \\
6 & 7.82 & 33.565 & 59.5495 & 1092.5 & 1235.75 & 4.5 \\
7 & 7.7 & 20.09 & 41.66688 & 1152.5 & 1233.25 & 4.7 \\
8 & 7.64 & 14.7 & 22.9525 & 1145 & 1228.75 & 4.8 \\
9 & 7.52 & 12.74 & 15.46675 & 1137.5 & 1225 & 4.7 \\
10 & 7.43 & 11.025 & 11.308 & 1157.5 & 1219.5 & 4.9 \\
\hline
\end{tabular}

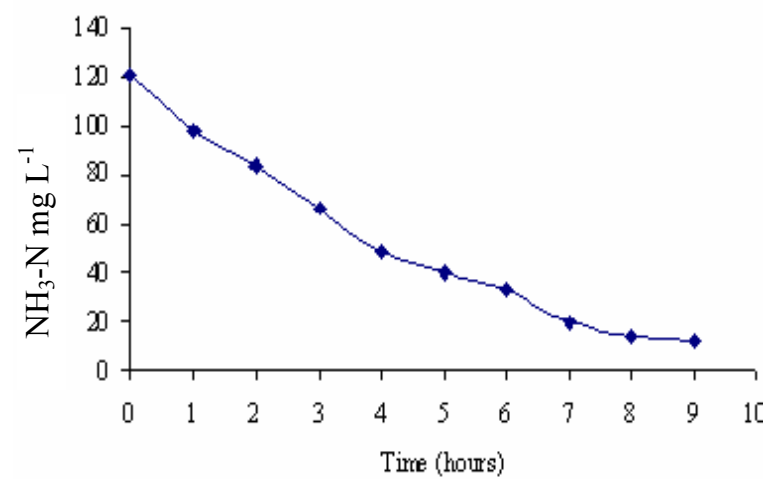

Fig. 2: The change of ammonia with time at the last cycle

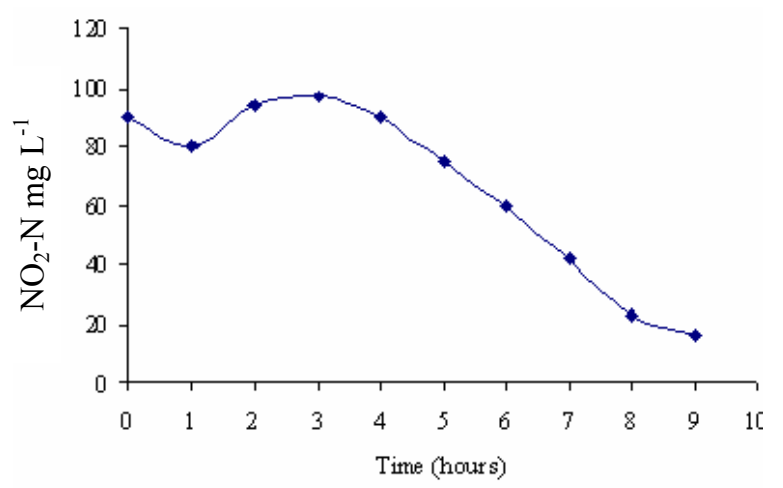

Fig. 3: The change of the nitrite with time at the last cycle

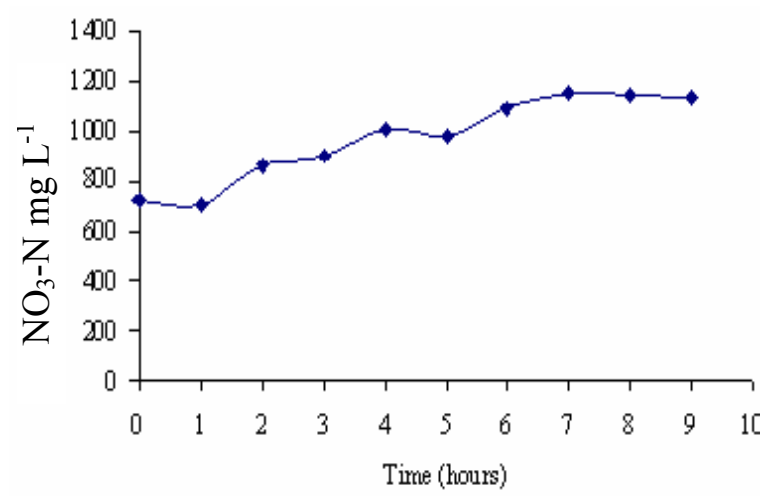

Fig. 4: The change of the nitrate with time at the last cycle

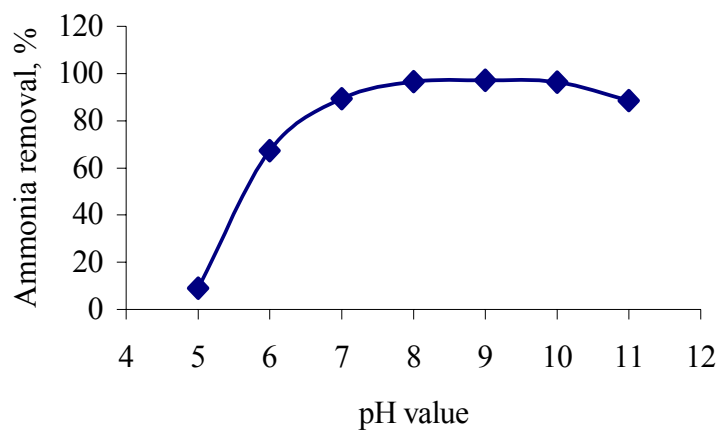

Fig. 5: Effect of $\mathrm{pH}$ value on the ammonia removal by using MAP precipitation at mole ratio $1: 1: 1$ 


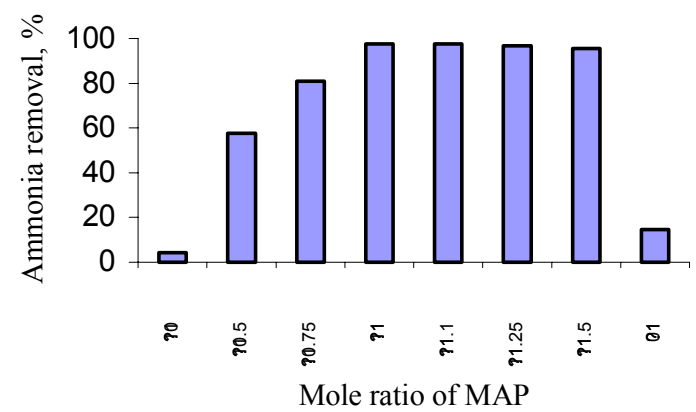

Fig.: 6 Percent of ammonia removal with different mole ratio at $\mathrm{pH}$ value is 9.0

\section{CONCLUSION}

1. The SBBR was shown to be a viable reactor system for treating the leachate. The laboratory study on the sequencing batch biofilm reactor (SBBR) resulted in the following conclusions:

* The SBBR can remove the ammonia effectively using adequate operation conditions.

* The highest ammonia removal was obtained with a nitrogen loading rate of $0.51 \mathrm{~kg} \mathrm{TN} / \mathrm{m}^{3}$ per day, and cycle time at 9 hours. The ammonia removal percent after treatment was $99 \%$, or $11 \mathrm{mg} / \mathrm{l}$ and met with Chinese standards for discharge.

2. As a pre-treatment process, the MAP precipitation was technically effective to remove the high $\mathrm{NH}_{3}$ $\mathrm{N}$ strength of over $1100 \mathrm{mg} / \mathrm{l}$ from the raw leachate at the mole ratio of 1:1:1, they demonstrated a very satisfactory removal of ammonia; an initial $\mathrm{NH}_{3}-\mathrm{N}$ concentration of $1100 \mathrm{mg} / \mathrm{l}$ contained in the raw leachate was quickly reduced to $28 \mathrm{mg} / \mathrm{l}$ within 15 min, while the $\mathrm{pH}$ producing a maximum removal of ammonia was 9.0. The percent removal of ammonia after treatment was $97.5 \%$.

3. The comparison between the two methods for removing ammonia from the old landfill leachate is as the following:

* The biological SBBR method is cheaper than the chemical method by using the MAP.

* For MAP precipitation method, a high salinity formed in the treated leachate during precipitation using $\mathrm{MgCl}_{2} \cdot 6 \mathrm{H}_{2} \mathrm{O}$ and $\mathrm{Na}_{2} \mathrm{HPO}_{4} \cdot 12 \mathrm{H}_{2} \mathrm{O}$, which may inhibit microbial activity in a following biological treatment process.

* The MAP precipitation method (just 15 minutes) is very faster than biological treatment that need more than 3 months.

* The two methods proved that they were very effective to remove the ammonia from old landfill leachate as shown in their results.

\section{REFERENCES}

1. Sutthipong Chanthikul, 1998, Computer Simulation of Leachate Quality Recirculation in a Sanitary Landfill Bioreactor, Msc. Thesis, the University of Texas at Arlington, USA.[doc.2]

2. P.R. O'leary, G. Tchobanoglous and F. Kreith (Eds.), 2002 Handbook of Solid Waste Management, McGraw-Hill, United States.

3. Kang, Y.W. and Hwang, K.Y., 2000, Effects of reaction conditions on the oxidation efficiency in the Fenton process, Water Res. Vol. 34, No. 10, pp. 2786-2790.

4. Knox K. and Jones P. H. (1979) Complexation characteristics of sanitary landfill leachates, Wat. Res. 13, 839-846.

5. Rowe RK, Quigley RM and Booker JR., 1997, Clayey barrier system for waste disposal facilities. E \& FN Spon, pp.1-45.

6. Julie-Marie Pouliot, 1999, Biological Treatment of Landfill Leachate, Msc. Thesis, the University of Western Ontario, London, Ontario, Canada.

7. Henung Jin Choi, 1998, Evaluation of Fenton process for the treatment of landfill leachate, A dissertation submitted to the faculty of the university of Delaware.

8. M. Teresa Vives Fabregas, 2004, SBR technology for wastewater treatment: suitable operational conditions for nutrient removal, PhD. Thesis, university of Girona.

9. Shilong He, Yu Zhang, Min Yang, Wenli Du, Hiroyuki Harada, 2007, Repeated use of MAP decomposition residues for the removal of high ammonium concentration from landfill leachate, Chemosphere 66, pp. 2233-2238.

10. X.Z. Li, Q.L. Zhao, X.D. Hao, 1999, Ammonium removal from landfill leachate by chemical precipitation, Waste Management 19, pp.409-415

11. Jaffer, Y., T.A. Clark, P. Pearce, and S.A. Parsons, 2002, Potential phosphous recovery by struvite formation, Wat. Res. 36, pp.1834-1842.

12. Burns R.T., L.B. Moody, I. Celen and J. R. Buchanan. 2002, Optimization of Phosphorus Precipitation from Swine Manure Slurries to Enhance Recovery, Water Sci. Technol. 1(48), pp.139-146.

13. Munch, E.V. and K. Barr. 2001, Controlled struvite crystallisation for removing phosphorus from anaerobic digester side streams, Wat. Res. 35, pp.151-159.

14. Çelen, I. and M. Türker 2001, Recovery of ammonia from anaerobic digester effluents. Environ, Technol., 22(11), pp.1263-1272.

15. Buchanan, J.R. 1993, Struvite Control in Flush Water Recycle Components of Livestock Waste, MSc Thesis, University of Tennessee, USA. 